\title{
THE EVOLUTION OF COMPARATIVE ADMINISTRATIVE LAW STUDIES
}

\author{
RENATA KUSIAK-WINTER*
}

\section{INTRODUCTION}

Administrative law is traditionally viewed as a distinct legal discipline with a high rate of inward looking elements which convey the uniqueness of the set of political, social, historical and economic conditions inherent in each state - hence, different from any solution followed elsewhere. As a basic instrument of control applied to social relationships in the state, administrative law has to be modified and adapted as required by the ever changing reality.

This necessity of responding to all changes in the immediate environment implies two important features of administrative law - its flexibility and its fragmentary nature which appear to contrast with the other branches of law. For example, civil law or criminal law are codified and comprise certain cannons of universal legal institutions such as a contract, inheritance or imprisonment or re-offending. Each of them should individually demonstrate a high degree of resistance to any political or economic changes. Encapsulated in a single act that provides a timeless guarantee of human and civil rights and regulates the most important systemic aspects of the state, constitutional law is rather reasonably expected to demonstrate a high degree of stability.

Administrative law is an entirely different matter being complex and heterogeneous, the concept of codification was abandoned at the start. It is the constantly changing reality of the administrative process that forces amendments to the legislation. One should bear in mind the fact that administrative law reflects the political vision of the ruling party. Therefore it may rather be hard to draw conclusions based on the letter of the law. The danger of "language traps" appears exceptionally realistic, also in the context of the whole realm of administrative studies. For example, on the one hand, administrative policy or sociology of administration exploits the universal language grid developed in political science or sociology and understood in all languages in the same way ${ }^{1}$. On the other hand, translating

DOI: $10.1515 /$ wrlae-2015-0046

* PhD in Law, Assistant Professor at the Institute of Administrative Sciences, Faculty of Law, Administration and Economics, University of Wrocław; renata.kusiakwinter@uwr.edu.pl 
and, what is more, understanding domestic administrative institutions in different countries in a harmonised way poses a daunting challenge ${ }^{2}$. The reason is that the conceptual framework of administrative law reflects the structural qualities of a single state which are deeply embedded in one particular system of administrative law ${ }^{3}$. In this spirit, one may adduce the following frequently quoted words of Ulrich Scheuner: "the structure of the state administration provides a special reflection of its unique nature and identity" . This line of thinking is also followed by Jan Jeżewski, who notes that "historical conditions have made an impact on many solutions applied to the member state administrative structures - which are, relatively, the least prone to harmonisation (institutional autonomy)" ". Therefore it appears that (in the case of an individual state) administrative law has built its own development paths, its unique discourse paradigms and self-observation mechanisms as regards to its doctrine and case-law ${ }^{6}$.

The above described inward looking character was the reason for administrative law being kept on the siding of legal comparative studies for many years. What made administrative law provide a focus for an intensive comparative inquiry was an urgent need for practical applications that was triggered by the expanding European integration and the globalisation of social and economic processes. The aim of this paper is to show the complex premises applied in comparative studies of administrative law and discuss the needs specific to academic research and practical applications the legislature, the judiciary and the executive. I will demonstrate that the research on comparative law significantly changed its ways and function over the years, but it has made a permanent contribution to a deeper reflection on applicable law.

\footnotetext{
${ }^{1}$ Geert Bouckaert, John Halligan, Managing Performance: International Comparisons (Routledge 2008); Sabine Kuhlmann, 'Performancesteuerung und Leistungsvergleich: Verwaltungsmodernisierung im kontinentaleuropäischen, angelsächsischen und skandinavischen Kontext' in Joachim Beck, Fabrice Larat (eds), Reform von Staat und Verwaltung in Europa - Jenseits von New Public Management? (Nomos 2011) 90.

${ }^{2}$ Veith Mehde, 'Verwaltungswissenschaft, Verwaltungspraxis und die Wissenschaft vom öffentlichen Recht - Eine Bestandsaufnahme' in Veith Mehde, Ulrich Ramsauer, Margrit Seckelmann (eds), Staat, Verwaltung, Information. Festschrift für Hans Peter Bull zum 75. Geburtstag (Duncker\&Humbolt 2011) 686.

3 Thomas Fleiner, 'Rechtsvergleichende Überlegungen zum Staatsverständnis in Ländern mit anglo-amerikanischer und kontinentaleuropäischer Rechtsordnung - Rechts- und staatsphilosophische sowie kulturelle Aspekte' in Peter Häberle, Martin Morlok, Wassilios Skouris (eds), Staat und Verfassung in Europa (Nomos 2000) 46.

${ }^{4}$ Ulrich Scheuner, 'Der Einfluss des französischen Verwaltungsrechts auf die deutsche Rechtsentwicklung' (1963) 17/18 Die Öffentliche Verwaltung 714.

5 Jan Jeżewski, 'Porównawcze badania prawa a europeizacja prawa administracyjnego` in Zbigniew Janku, Zbigniew Leoński, Marek Szewczyk, Michał Waligórski, Krystyna Wojtczak (eds), Europeizacja polskiego prawa administracyjnego (Kolonia Limited 2005) 55.

6 Eberhard Schmidt-Aßmann, Stéphanie Dagron, 'Deutsches und französisches Verwaltungsrecht im Vergleich ihrer Ordnungsideen - Zur Geschlossenheit, Offenheit und gegenseitigen Lernfähigkeit von Rechtssystemen` (2007) 67 Zeitschrift für ausländisches öffentliches Recht und Verwaltungsrecht 395.
} 


\section{The NeEdS OF ACADEMIC RESEARCH}

Comparative legal research is originally and primarily premised on a scholarly urge to explore the legal solutions of another state - a motivation that is derived from one's curiosity and determination to improve one's knowledge. It should be emphasised that comparative studies have a cognitive purpose, and thereby an academic value, even if no clear and precise research goal has been set. Nonetheless, in reality, they always provide a starting point for further research projects. They facilitate universal communication among scholars in academia, support the teaching of law and improve the quality of studies on one's own legal order'.

Bearing in mind the centuries-old tradition of civil law that dates back to the period of the Roman Empire, administrative law - as developed in the continental Europe in the $19^{\text {th }}$ century - is a young discipline of law. When the primary premises of comparative research in these two realms of law are contrasted it becomes clear that, due to the common roots and shared traditions, the trend in civil law was to unify or at least harmonise its major institutions beyond borders. Administrative law was however created by each sovereign state separately and therefore the focus was on the learning aspect ${ }^{8}$.

Once applied to the reality of Poland, the above thinking will reveal an important special case. The period of time when administrative law was created and formed also saw Poland losing its statehood. It is symptomatic, in particular if we recognise the natural and indispensable bond between the administration and the state. After all it was the state that would establish administrative law and provide the foundation of a strong and efficient administration in order to attain its ambitious goals and strengthen its position. Where there was no state there was de facto no administration. With no statehood the comparative studies conducted at that time by local experts referring to the best European models ${ }^{9}$ fulfilled an important integrating role when independence was regained. The research was a unique and important link for administrative law to define itself as a branch of law and gain coherence as a separate and self-contained research discipline. Interestingly, the first Polish handbook of administrative law by Antoni Okolski was inevitably comparative by nature and based on the laws of Prussia, Austria and Russia ${ }^{10}$. Furthermore, the restoration of the Polish

\footnotetext{
${ }^{7}$ Thomas Groß, 'Rechtsvergleichung` (2015) 48 Die Verwaltung 581.

8 Christoph Schönberger, 'Verwaltungsrechtsvergleichung: Eigenheiten, Methoden und Geschichte' in Armin von Bogdandy, Sabino Cassese, Peter M. Huber (eds), Handbuch Ius Publicum Europaeum: Verwaltungsrecht in Europa: Wissenschaft, vol 4 (C.F. Müller 2011) 499.

9 Fryderyk hrabia Skarbek, Gospodarstwo narodowe. Elementarne zasady gospodarstwa narodowego, vol I-II, (Biblioteka Wyższej Szkoły Handlowej 1820); Józef Bohdan Oczapowski, Policyści zeszłego wieku i nowożytna nauka administracji. Historia nauki administracji w XVIII wieku (Drukiem S. Orgelbranda Synów 1882); Franciszek Ksawery Kasparek, Prawo polityczne ogólne z uwzględnieniem austriackiego razem ze wstepna nauka ogólna o państwie, vol I-II (Kraków 1877-1881).

10 Antoni Okolski, Wykład prawa administracyjnego oraz prawa administracyjnego obowiąującego w Królestwie Polskim (vol. I - 1880, vol II - 1882, vol III - 1884). See Eugeniusz Ochendowski, 'Pierwszy polski podręcznik prawa administracyjnego. W
} 
state in 1918 was naturally accompanied with resorting to the legal solutions followed by the former partitioners as much as those applied in France or England. They were subsequently adopted to serve the purpose of the country's territorial division and administrative courts. One may hazard a guess that in the absence of the state, the inspiration that comes from the solutions offered by a foreign system of administrative law and the ownership of these solutions may foster a sense of continuity of the state, and in the long term, promote creating an identity in the meaning of legal tradition $^{11}$.

The history of comparative law studies in Poland shows that comparative research played an important role not only in the days of statelessness but also in the era of the Polish People's Republic, known by the acronym of the PRL. A monograph on the legal position of an individual to the activities of public authorities in some West European States by Franciszek Longchamps de Bérier is a meaningful example ${ }^{12}$. By describing western standards his work induced reflection on the absence of safeguards protecting the individual against the lawlessness of the people's rule and thereby it turned out to be a voice of silent critique ${ }^{13}$. Comparative law played an instrumental role to this effect by integrating different circles of administrative professionals around the fundamental values of public administration - the values of the democratic state.

In its early days comparative law had yet one more important function - the one of building the systematics of administrative law. Considered the "cradle" of administrative law, France became the destination for seeking its best models. The French solutions found their great apologist in Otto Mayer. Before writing his handbook that de facto established administrative law in Germany, he had completed a thorough analysis of French institutions ${ }^{14}$. The greatest credit should probably go to him for conceptualising the administrative act as the fundamental form of the activities of the public administration in the state of law ${ }^{15}$. Interestingly, the concept of the administrative act was adopted by most of European states in the form proposed by Otto Mayer rather than imported directly from France, a clear evidence of the importance of comparative reflection in administrative law ${ }^{16}$.

The development of the public service doctrine and the service administration doctrine is another important example showing how the

stulecie wydania podręcznika A. Okolskiego` (1981) 1 Organizacja, Metody, Technika 2728.

${ }^{11}$ Andrzej Wróbel, 'Landesspezifische Ausprägungen: Polen` in Armin von Bogdandy, Sabino Cassese, Peter M. Huber (eds), Handbuch Ius Publicum Europaeum: Verwaltungsrecht in Europa: Grundlagen, vol 3 (C.F. Müller 2010) 238, 243 et seq.

12 Franciszek Longchamps de Bérier, Współczesne kierunki $w$ nauce prawa administracyjnego na zachodzie Europy (Zakład Narodowy im. Ossolińskich 1968).

13 Irena Lipowicz, 'Einfluss des deutschen Verwaltungsrechts auf die Lehre des Verwaltungsrechts in Polen` (2015) 48 Die Verwaltung 370.

${ }^{14}$ Otto Mayer, Theorie des Französischen Verwaltungsrecht (Trübner 1886).

15 Reimund Schmidt-De Caluwe, Der Verwaltungsakt in der Lehre Otto Mayers (Mohr Siebeck 1999).

16 Otto Mayer significantly influenced the development of the first handbooks of administrative law in Italy and Spain. See Vittorio Emanuele Orlando (ed), Primo trattato completo di diritto amministrativo (Cammeo\&Vitta 1897); Adolfo Posada, Tratado de Derecho administrativo (Suárez 1893). 
comparative method is employed in the quest for a systematics of administrative law terms and institutions. In this case the starting point was to analyse the French institution of service public from the perspective proposed by Léon Duguit and his followers including such renowned administrative law experts as Gaston Jèze or André de Laubadère ${ }^{17}$. On the ground of German law, the development of this conception into Lestungsverwaltung and Daseinsvorsorge was fostered by the work of Ernst Forsthoff $^{18}$ who exerted a decisive impact on the work of Polish administrative law experts, such as Tadeusz Kuta ${ }^{19}$ or Ernest Knosala ${ }^{20}$.

The above cited examples show the importance of comparative research for the making and developing of the classic administrative institutions. It should be emphasised that in addition to the analysis of foreign law the key method employed in scientific or scholarly cognition is verifying the dogmatic rationale that invokes the elementary principles and values underpinning the established legal solutions in question.

A discussion of the role of comparative studies for the needs and development of academic research must allow for an account of contemporary problems. In particular, in the context of European integration it transpires that there is no raison d'être for a one-way reception pattern with regard to the transfer of administrative law dogma from one state to the other. What we can observe in practice is a multidirectional mechanism of mutual learning with its starting point being the traditional institutions of administrative law. It is in the course of the process that they are transformed under the influence of supranational mechanisms ${ }^{21}$.

The above changes will be best illustrated with the development of the classic forms of operation employed within administrative law under the influence of European law. A transnational administrative act relates in many points to the mechanism operating in the different member states ${ }^{22}$ but the cooperation within the European public administration network requires a new conceptualisation. This type of cooperation does not match any classical category applied to the cooperation of public entities within a

\footnotetext{
${ }^{17}$ Gilles J. Guglielmi, Une introduction du droit de service public (LGDJ 1994) 5-7.

18 Ernst Forsthoff, Die Verwaltung als Leistungsträger (Kohlhammer 1938); Ernst Forsthoff, Rechtsfragen der Leistenden Verwaltung (Kohlhammer 1959); Irena Lipowicz, 'Pojęcie administracji świadczącej w doktrynie zachodnioniemieckiej' in Karol Podgórski (ed), Regulacja prawna administracji świadczącej (Uniwersytet Śląski 1985) 131 et seq.

19 Tadeusz Kuta, Aspekty prawne działań administracji publicznej w organizowaniu ustug (Zakład Narodowy im. Ossolińskich 1969); Tadeusz Kuta, Funkcje współczesnej administracji $i$ sposoby jej realizacji (1992) Acta Universitatis Wratislaviensis. Prawo CCXVII 12 et seq.

20 Ernest Knosala, 'Pojęcie administracji świadczącej w polskiej literaturze prawa administracyjnego` in Karol Podgórski (ed), Regulacja prawna administracji świadczacej (Uniwersytet Śląski 1985) 16.

21 Stephan Neidhardt, Nationale Rechtsinstitute als Bausteine europäischen Verwaltungsrechts. Rezeption und Wandel zwischen Konvergenz und Wettbewerb der Rechtsordnungen (Mohr Siebeck 2008).

${ }^{22}$ Luca de Lucia, Administrative Pluralism, Horizontal Cooperation and Transnational Administrative Acts` (2012) 5 (2) Review of European Administrative Law 42; Dawid Miąsik, Andrzej Wróbel, 'Europeizacja prawa administracyjnego - pojęcia i konteksty` in Roman Hauser, Andrzej Wróbel, Zygmunt Niewiadomski (eds), Europeizacja prawa administracyjnego. System Prawa Administracyjnego, vol 3 (C.H. Beck 2014) 22.
} 
single legal system of an individual country ${ }^{23}$. This cooperation is highly informal. It involves exchanging information, coordinating activities and giving recommendations and guidelines. In accordance with the administrative doctrine, however, new legal constructs should comply with the same basic requirements and standards as those set for the cooperation among public entities at the national level. Therefore, in the comparative perspective we are expected to demand that democratic control and accountability be enforced, especially when liaising authorities are not limited to entities from the EU member states but also originate from thirdparty states $^{24}$.

\section{THE NeEDS OF THE LEgisLATURE}

It is transfer of law as a fundamental function of comparative legal research that has come to the fore of the legislative process. Complex codified regulations or individual legal institutions are not transferred on the one-to-one basis. They are subject to adjustment and adaptation in the course of the legislative process ${ }^{25}$. All transfers of laws are guided by the principle of practical legislative need. It is, however, important to realise that they are accompanied and promoted by a set of specific conditions.

The first and obvious condition is for the legislator to be open and willing to explore and exploit other models. From a historical perspective the $19^{\text {th }}$ century is defined as the "age of comparison" in literature. As regards legal scholarship, the rule of supranational laws of nature came to an end. The shared pan-European body of law written in Latin was also discarded. They would be all replaced by constitutions enacted in national languages and Napoleon would trigger a large scale consolidation of national law through its codification. The building up of national awareness and the fostering of a sense of state identity was accompanied by exceptional openness and a zest to draw on external legal models. As noted by Christoph Schönberger, the European constitutions enacted at short intervals were developed as closely interdependent, mutually related acts and reacted to each other accordingly ${ }^{26}$.

In Poland this opening could only take place when the country regained its independence in 1918. The reception of the Austrian administrative code, to be precise one of the bills drafted in 1925, provides

\footnotetext{
${ }^{23}$ Jerzy Supernat, 'Koncepcja sieci organów administracji publicznej’ in Jan Zimmermann (ed), Koncepcja systemu prawa administracyjnego (Wolters Kluwer 2006) 207.

${ }^{24}$ Peter M. Huber, 'Grundzüge des Verwaltungsrechts in Europa - Problemaufriss und Synthese' in Armin von Bogdandy, Sabino Cassese, Peter M. Huber (eds), Handbuch Ius Publicum Europaeum: Verwaltungsrecht in Europa: Grundzüge, vol 5 (C.F. Müller 2014) 23.

${ }^{25}$ A chemical term of "transfer" is deliberately used to make the reader realise law in the process of transfer is seen as a special laboratory providing capacity to weigh the letter of law and measure legal reality, see Margrit Seckelmann, 'Ist Rechtstransfer möglich? Lernen vom fremden Beispiel' (2012) 43 Rechtstheorie 425.

26 Chistoph Schönberger 'Verwaltungsrechtsvergleichung: Einheiten, Methoden und Geschichte' in Armin von Bogdandy, Sabino Cassese, Peter M. Huber (eds), Handbuch Ius Publicum Europaeum: Verwaltungsrecht in Europa: Wissenschaft, vol 4 (C.F. Müller 2011) 520-521.
} 
an excellent example of the process. Enacted in 1928 and most recently revised in 1960, the code ${ }^{27}$ was given very favourable reviews and has since continued to successfully serve its purpose and exert a powerful impact on the subsequent development of the administrative law and doctrine in Poland. The institution of territorial self-government of the $2^{\text {nd }}$ Republic also exhibited many common features shared with the models largely followed in the Europe of the day ${ }^{28}$. Considering the closed character of the political system in the cold war era, it is important to bear in mind that this type of openness is not inherent or installed once and forever in legal culture $^{29}$.

Second, what in addition to openness stimulates all law-transfer efforts is the occurrence of similar problems or issues which have already been addressed with a comprehensive legal solution by other states. To cite the example of Poland, after the 1989 transformation of its polity, the country faced a challenge of passing an administrative law to protect the right to privacy. The Act on the Protection of Personal Data was enacted in 1997. It reputedly drew on the law of the federal state of Hesse. In 1970, Hesse passed the world's first act on the processing of personal data by a public administration entity (or an entity authorised to provide or operate public services $)^{30}$. This example clearly shows that from the legislator's angle, the process of transferring laws must equally focus on the text of a law and the practical experience of its implementation and operation. In the above example, the Hessian law had been reviewed and amended on many occasions in the process of mutual learning and interacting of the German state legislatures on the federal level. It was not without significance that a well-established case-law had already existed inclusive of the Federal Constitutional Court's decisions ${ }^{31}$. Much as the European legislation compels the adoption of a new formula for personal data protection to keep pace with the progress of technology and respond to the increase in data volume on a gigantic scale ${ }^{32}$, the merits and consequence of the existing law must not go unnoticed. Inspired by foreign legislation and ably modified to accommodate specific Polish needs and requirements it is seen as a remarkable achievement of the Polish legislative effort ${ }^{33}$.

\footnotetext{
${ }^{27}$ Regulation of the President of the Republic of Poland of 22 March 1928 on administrative proceedings, Dziennik Ustaw - Official Journal of Laws of the Republic of Poland (hereinafter: Dz. U.) No 36, item 341. For broader treatment see Władysław Czapiński, 'Nowe prawo o postępowaniu administracyjnym' (1928) 4 Gazeta Administracji i Policji Państwowej 289 et seq.

28 Jerzy Panejko, Geneza i podstawy samorządu europejskiego (Imprimerie de Navarre 1926); Tadeusz Bigo, Samorzad terytorialny w nowej konstytucji in Księga pamiątkowa ku czci Leona Pinińskiego (Komitet Redakcyjny 1936).

${ }^{29}$ Janusz Łętowski, 'Comparative Law Science in So Called Applied Fields of Law` (1991) 2 Comparative Law Review 30.

${ }^{30}$ Lipowicz (n 14) 375.

${ }^{31}$ See in particular judgement Bundesverfassungsgericht, BVerfGE 65, 1 (44).

32 Regulation (EU) 2016/679 of the European Parliament and of the Council of 27 April 2016 on the protection of natural persons with regard to the processing of personal data and on the free movement of such data, and repealing Directive 95/46/EC (General Data Protection Regulation), OJ L 119, 4.5.2016, 1-88. To take effect from 25 May 2018.

${ }^{33}$ As noted by Irena Lipowicz ,The (..) regulation of the European Parliament and of the Council is practically supposed to supersede the current Data Protection Act - our pride and
} 
Third, the main focus and dominant object of modern comparative studies carried out for the needs of the legislature are institutional factors and determinants. It is true that the institution of federal states provides a natural platform for a regular transfer of the best legal solutions since federal states traditionally engage in specific competition in developing the best legislative models ${ }^{34}$, however the membership in supranational organisations has led to the development of law transfer on an unprecedented mass scale despite cultural and linguistic barriers.

Clearly, European administrative law is a result of mutual receptiveness between the states and the Union. In order to make and improve European laws the EU refers to national legal mechanisms which have evolved over time in a specific cultural environment. Such mechanisms are modified, adapted and diversified. Once transplanted, they influence the national law order, for example, indigenous national mechanisms which were originally employed as their prototypes ${ }^{35}$. In this situation the system may reach a turning point due to the effect known as a spill-over into national law. A spill-over involves an effect produced by EU law - through its mandatory presence within the national system - on such areas of domestic law where EU bodies may not claim any competence to interfere. A consequence of this process is the convergence of national law $^{36}$.

Top-down mandatory transfers of law within supranational structures appear to reveal cultural differences. A useful example is the right to good administration established under article 41 of the Charter of Fundamental Rights basing on the original model from Scandinavian culture ${ }^{37}$. The idea of creating a subjective right of an individual to good administration in the continental systems of public administration appears to be at odds with the concept of individual rights derived from the fundamental rights enshrined in the constitution. The "oddity" comes from the difference between the Scandinavian tradition that follows the ideal type of adjective (procedural) law - the ideal type of legal procedure and the continental (German or French) tradition with its formalist ideal type relating to the enforcement of fundamental rights ${ }^{38}$. The critics suggest that the transfer may in this particular case open the door to the harmonisation of national administrations, albeit with no actual competence on the part of the EU

our own achievement - in the Polish legal system", see Irena Lipowicz in 1998-2013 15 Years of the Act on the Protection of Personal Data in Poland (GIODO 2013) 34.

${ }^{34}$ In this sense the competition of public entities for "the best" legal regulations has been discussed in the literature for years now (the so-called competition of legal orders), see Veith Mehde, Wettbewerb zwischen den Staaten (Nomos 2005); Henning Jensen, Kommunale Daseinsvorsorge im europäischen Wettbewerb der Rechtsordnungen (Mohr Siebeck 2015).

${ }^{35}$ To quote the example of the protection of legitimate expectations that was established in German case-law and subsequently adopted by the ECJ for the purpose of its decisions. It should be noted that while the said institution guarantees full protection in Germany, in EU law, the ECJ has reduced it to the status of limited exceptional application. See Neidhardt (n 22) 138.

${ }^{36}$ Ibid

37 Kai-Dieter Classen, Gute Verwaltung im Recht der Europäischen Union. Eine Untersuchung zur Herkunft, Entstehung und Bedeutung des Art 41 Ab 1 und 2 der Europäischen Grundrechtecharta (Duncker\&Humbolt 2008) 74-94.

${ }^{38}$ Gunnar Folke Schuppert, Politische Kultur (Nomos 2008) 711. 
bodies $^{39}$. There is a concern over national administration being seen as detached from the state ${ }^{40}$.

The above discussion clearly demonstrates that non-obligatory, elective, law transfers are conditional on the recipient system of law being open and showing a range of similar problems and issues which require legal solutions. Such transfers are carried out on the sole initiative and at the option of the legislator. Apparently, with regard to their goals and methods, comparative studies do not concentrate so much on the rendition of the "transferred" normative act or the existing case law and an established line of authority for their chief purpose is to capture the common conditions and values lying behind the idea of legislative changes. While scholarly comparative research aims at treating different legal orders in an equal manner to capture their commonalities and differences, comparative research carried out for the needs of the legislator of a specific state shall deal with the transferred law in an instrumental manner with efforts to be expended on its adaptation to the needs of the legal order of the recipient state, which is the reason why the transfer results in a new and independent legislative product that widely differs from the original model.

Meanwhile, the obligatory transfers of law completed in supranational organisations on a massive scale strive for the goal of ensuring that the law of the member states reaches a set degree of unification. In these circumstances, comparative studies begin with the awareness that the imposed regulations are not invented in a legislative vacuum but come from certain national legal orders. Comparative research should then be conducted at multiple stages. First to deal with the model legislation. Second, to accommodate the supranational legislator's alterations and improvements. Third, to examine, in the context of the results obtained at stages one and two, how the legal mechanism operates in the recipient law. The comparative research employs for this purpose a highly complex and comprehensive method that involves the knowledge of the letter of law, the applied line of authority and case-law as much as a broad cultural context of the law that is the object of the studies.

\section{The NeEDS OF THE EXECUTIVE AND THE NEEDS OF THE JUDICATURE}

The purpose of the executive branch and the judicature is to enforce the applicable law by putting it into operation and examining disputes which arise in connection with the enforcement and operation of the law. As opposed to the legislature, which is vested with law making power and not unreasonably expected to utilise the best (also foreign) models, the executive or the judiciary should not, as a point of principle, search for inspiration elsewhere in the process of applying law. Used as a reference or

\footnotetext{
${ }^{39}$ Seckelmann (n 26) 425

${ }^{40}$ Armin von Bogdandy 'Verwaltungsrecht im europäischen Rechtsraum - Perspektiven einer Disziplin ' in Armin von Bogdandy, Sabino Cassese, Peter M. Huber (eds), Handbuch Ius Publicum Europaeum. Verwaltungsrecht in Europa: Wissenschaft, vol 4 (C.F. Müller 2011) 5 .
} 
a benchmark, legal solutions developed in a different legal culture, hence alien to the circumstances and reality of one's domestic administration process, carry a dangerous potential to treat comparative studies in an instrumental way and exploit them in passing discretionary or probabilistic decisions $^{41}$.

It is the principle of territoriality that guides public authorities in applying law. This is also where the main difference lies as regards civil law. While civil law is founded on the freedom of contract that manifests itself in the contracting parties having freedom to decide on applicable law (private international law), in administrative law, the essence of which is to exercise administrative power, a reference to a foreign law would be most unusual. This situation arises from one of the discriminants of administrative law, namely the fact that its enforcement is completely related to the state territory, in line the principle of territorial jurisdiction that governs the operation of public authorities and controls their power by determining the scope of their local competence (rationae loci) and subject matter competence (rationae materiae) ${ }^{42}$. Physical persons (individuals) may engage in their activities in a relatively flexible manner, enjoy the freedom of movement in space ${ }^{43}$ or even a relative freedom of choice of state $^{44}$, or ultimately, the freedom to subject themselves to law of their choice. As products of the country's legal order designed to serve the enforcement of public law, public administration-controlled entities have no such option. Therefore, public administration bodies and courts of law will not apply foreign law unless domestic law explicitly licenses them to do so ${ }^{45}$. Furthermore, administrative law never requires that foreign law be applied in toto, but only to a limited extent. There is a doctrinal consensus with

\footnotetext{
${ }^{41}$ Martin Bullinger, 'Zwecke und Methoden der Rechtsvergleichung im Zivilrecht und im Verwaltungsrecht' in Ingeborg H. Schwenzer, Günter Hager (eds), Festschrift für Peter Schlechtriem zum 70. Geburtstag (Mohr Siebeck 2003) 337.

42 The territorial principle is given full weight in the judgement of the Supreme Administrative Court of 25 August 2011 (I OSK 1769/10) where the court emphasises that the provisions of the Polish Road Traffic Act of 20 June 1997 (Prawo o ruchu drogowym, Dz. U. No 98, item 602) with regard to taking one's driving licence should also be applied to a driving licence issued by the public administration in Germany.

43 Free movement of people is a fundamental right granted to all citizens of European Union by virtue of the Treaties, see art $3 t \sec 2$ of the Treaty on European Union (Dz. U. 2004, No 90, item 864/30), art 21 and Titles IV and V of the Treaty on the Functioning of the European Union (OJ C 83, 30.03.2010, 47, consolidated version); Directive 2004/38/EC on the right of citizens of the Union and their family members to move and reside freely within the territory of the EU and EEA member states (OJ L 158, 30.4.2004).

${ }^{44}$ Art $34 \mathrm{sec} 2$ of the Constitution of the Republic of Poland of 2 April 1997 (Dz. U. 1997, No 78, item 483 as amended) provides that Polish citizenship is lost by renunciation. Art 46 of the Polish Citizenship Act (ustawa z dnia 2 kwietnia 2009 r. o obywatelstwie polskim, Dz. U. 2012, item 161) provides that a Polish citizen who has renounced his or her citizenship shall lose the same when he or she obtains the consent of the President of the Republic of Poland to renunciation of Polish citizenship.

45 The majority of the cases are the so-called transnational administrative acts issued by an administration body of one the member states and enforceable in the other members states by virtue of EU law. On this subject see Barbara Kowalczyk, 'Zasada terytorializmu działania administracji a transgraniczność spraw administracyjnych' in Renata KusiakWinter (ed), Wspótpraca transgraniczna $w$ administracji publicznej (E-Wydawnictwo. Prawnicza i Ekonomiczna Biblioteka Cyfrowa. Wydział Prawa, Administracji i Ekonomii Uniwersytetu Wrocławskiego 2015) 157-166.
} 
regard to the problematic issue of how to apply colliding norms in administrative law on the pattern of international private law ${ }^{46}$.

The fact that the territorial principle remains in force does not mean that comparative studies are to be completely abandoned. Indeed, it is about linguistic interpretation being the central element in the process of applying law. Therefore, where linguistic interpretation fails to provide a clear-cut result the body responsible for the enforcement of administrative law will have to turn to functional, systematic or another type of interpretation to disambiguate the outcome of the linguistic interpretation ${ }^{47}$. In the context of the EU membership, the EU interpretation of law must prevail as substantiated in many examples of the ECJ case-law. The European Court of Justice indicates that the idea does not come down to implementing EU law but expands on the community-friendly harmonisation of national law during the process of its application ${ }^{48}$. Mindful of this purpose, comparative studies should concentrate on analysing the legal orders of the member states with special attention to the convergence resulting from the primacy of EU interpretation of law. Interestingly, reverse situations may also occur. Comparative studies of the constitutional practices in the EU member states provides examples to illustrate them. It concerns the fact that constitutional courts of the EU member states widely invoke the Solange doctrine developed by the German Federal Constitutional Court (Bundesverfassungsgericht) in justifying the precedence of the national constitution over the EU law ${ }^{49}$.

The above indicates that comparative studies of application of law have different functions - searching for ideas, providing solutions to specific problems, equipping courts of law in a form of dialogue, helping optimise the normative argument used in justifications of judicial decisions or normative acts, serving as argumentation ornaments ${ }^{50}$. Nonetheless, it should be emphasised that comparative research must not aspire to dominate or lead the law application process, for the central argument rests on the goals and functions of applicable law.

\footnotetext{
46 Marek Zieliński, `O pojęciu międzynarodowego prawa administracyjnego' (2008) 9 Państwo i Prawo 28; Martin Kment, Grenzüberschreitendes Verwaltungshandeln. Transnationale Elemente deutschen Verwaltungsrechts (Mohr Siebeck 2010).

${ }^{47}$ A contrario it should be noted - to invoke a judgement of the Supreme Administrative Court - that the EU-friendly interpretation must not be employed if it produces an outcome that will contradict the effects of linguistic interpretation, which in turn may trigger the unacceptable contra legem interpretation (NSA judgement of 5 October 2016 I FSK $1106 / 16)$.

${ }^{48}$ Miąsik, Wróbel (n 23) 78.

49 The Solange doctrine has won approval of the Constitutional Court in Poland, see Judgement of 11 May 2005, K 18/04, OTK-A 2005, No. 5, item 49. On this subject see Bogusław Banaszak, Limitation of Sovereignty by the European Integration - The Polish Approach in Rainer Arnold (ed), Limitations of National Sovereignty through European Integration (Springer 2016) 99-108.

${ }^{50}$ Miąsik, Wróbel (n 23) 10.
} 


\section{CONCLUSION}

Comparative administrative studies pose a difficulty with regard to a clear division between the academic research goals and the research goals set to cater for the needs of the legislative process or the practical application of law (the executive and the judicature). The interests invariably centre on a deep analysis of two independent legal orders allowing for commonalities and differences, interdependence, determinants and cause-and-effect relationships. Comparative studies are on every level of research premised to attain cognitive goals, explore new ideas, search for development impulses or new problem-solving methods, build bridges and communication, attain the goals of reflection, judgement and learning from others. They also facilitate the quest for methods to systematise both new phenomena and the existing ones.

The nature and scope of comparative studies is traditionally determined by the unique character of administrative law with its high rate of insular elements accounting for the characteristics of different states. Comparative studies are also flexible (variable) and fragmentised by nature. These two qualities appear to remain valid but the insular characteristics have been largely reduced as a result of loosening the ties of the administration with the state. This consequently influences comparative studies as we may draw a clear dividing line between the research on independent legal orders in the phase of no connections among the states and the phase of a high degree of interdependence and interaction among the legal orders in the membership frame of supranational organisations such as European Union. With European law in place reducing top-down the insular elements of administrative law, comparative studies should focus on the cultural and axiological context of pliancy or resistance to any further efforts stimulating convergence.

\section{References}

Banaszak Bogusław, Limitation of Sovereignty by the European Integration - The Polish Approach in Arnold Rainer (ed), Limitations of National Sovereignty through European Integration (Springer 2016)

Bigo Tadeusz, Samorzad terytorialny $w$ nowej konstytucji in Ksiega pamiatkowa ku czci Leona Pinińskiego (Komitet Redakcyjny 1936)

Bogdandy Armin von, 'Verwaltungsrecht im europäischen Rechtsraum Perspektiven einer Disziplin' in Bogdandy Armin von, Cassese Sabino, Huber Peter M. (eds), Handbuch Ius Publicum Europaeum. Verwaltungsrecht in Europa: Wissenschaft, vol 4 (C.F. Müller 2011)

Bouckaert Geert, Halligan John, Managing Performance: International Comparisons (Routledge 2008)

Bullinger Martin, 'Zwecke und Methoden der Rechtsvergleichung im Zivilrecht und im Verwaltungsrecht' in Schwenzer Ingeborg H., Hager Günter (eds), Festschrift für Peter Schlechtriem zum 70. Geburtstag (Mohr Siebeck 2003) 
Classen Kai-Dieter, Gute Verwaltung im Recht der Europäischen Union. Eine Untersuchung zur Herkunft, Entstehung und Bedeutung des Art 41 Ab 1 und 2 der Europäischen Grundrechtecharta (Duncker\&Humbolt 2008) Czapiński Władysław, 'Nowe prawo o postępowaniu administracyjnym' (1928) 4 Gazeta Administracji i Policji Państwowej

Fleiner Thomas, 'Rechtsvergleichende Überlegungen zum Staatsverständnis in Ländern mit anglo-amerikanischer und kontinentaleuropäischer Rechtsordnung - Rechts- und staatsphilosophische sowie kulturelle Aspekte' in Häberle Peter, Morlok Martin, Skouris Wassilios (eds), Staat und Verfassung in Europa (Nomos 2000)

Forsthoff Ernst, Die Verwaltung als Leistungsträger (Kohlhammer 1938); Ernst Forsthoff, Rechtsfragen der Leistenden Verwaltung (Kohlhammer 1959)

Groß Thomas, 'Rechtsvergleichung' (2015) 48 Die Verwaltung

Guglielmi Gilles J., Une introduction du droit de service public (LGDJ 1994)

Henning Jensen, Kommunale Daseinsvorsorge im europäischen Wettbewerb der Rechtsordnungen (Mohr Siebeck 2015)

Huber Peter M., 'Grundzüge des Verwaltungsrechts in Europa Problemaufriss und Synthese' in Bogdandy Armin von, Cassese Sabino, Huber Peter M. (eds), Handbuch Ius Publicum Europaeum: Verwaltungsrecht in Europa: Grundzüge, vol 5 (C.F. Müller 2014)

Jeżewski Jan, 'Porównawcze badania prawa a europeizacja prawa administracyjnego' in Janku Zbigniew, Leoński Zbigniew, Szewczyk Marek, Waligórski Michał, Wojtczak Krystyna (eds), Europeizacja polskiego prawa administracyjnego (Kolonia Limited 2005)

Kasparek Franciszek Ksawery, Prawo polityczne ogólne z uwzględnieniem austriackiego razem ze wstępna nauka ogólna o państwie, vol I-II (Kraków 1877-1881)

Kment Martin, Grenzüberschreitendes Verwaltungshandeln. Transnationale Elemente deutschen Verwaltungsrechts (Mohr Siebeck 2010)

Knosala Ernest, 'Pojęcie administracji świadczącej w polskiej literaturze prawa administracyjnego' in Podgórski Karol (ed), Regulacja prawna administracji świadczacej (Uniwersytet Śląski 1985)

Kowalczyk Barbara, 'Zasada terytorializmu działania administracji a transgraniczność spraw administracyjnych` in Kusiak-Winter Renata (ed), Wspótpraca transgraniczna $w$ administracji publicznej (E-Wydawnictwo. Prawnicza i Ekonomiczna Biblioteka Cyfrowa. Wydział Prawa, Administracji i Ekonomii Uniwersytetu Wrocławskiego 2015)

Kuhlmann Sabine, 'Performancesteuerung und Leistungsvergleich: Verwaltungsmodernisierung im kontinentaleuropäischen, angelsächsischen und skandinavischen Kontext' in Beck Joachim, Larat Fabrice (eds), Reform von Staat und Verwaltung in Europa - Jenseits von New Public Management? (Nomos 2011)

Kuta Tadeusz, Aspekty prawne działań administracji publicznej $w$ organizowaniu ustug (Zakład Narodowy im. Ossolińskich 1969)

Kuta Tadeusz, Funkcje wspótczesnej administracji i sposoby jej realizacji (1992) Acta Universitatis Wratislaviensis. Prawo CCXVII 
Łętowski Janusz, 'Comparative Law Science in So Called Applied Fields of Law` (1991) 2 Comparative Law Review

Lipowicz Irena in 1998-2013 15 Years of the Act on the Protection of Personal Data in Poland (GIODO 2013)

Lipowicz Irena, 'Einfluss des deutschen Verwaltungsrechts auf die Lehre des Verwaltungsrechts in Polen ' (2015) 48 Die Verwaltung

Lipowicz Irena, 'Pojęcie administracji świadczącej w doktrynie zachodnioniemieckiej' in Podgórski Karol (ed), Regulacja prawna administracji świadczacej (Uniwersytet Śląski 1985)

Longchamps de Bérier Franciszek, Współczesne kierunki w nauce prawa administracyjnego na zachodzie Europy (Zakład Narodowy im. Ossolińskich 1968)

Lucia Luca de, 'Administrative Pluralism, Horizontal Cooperation and Transnational Administrative Acts' (2012) 5 (2) Review of European Administrative Law 42

Mayer Otto, Theorie des Französischen Verwaltungsrecht (Trübner 1886)

Mehde Veith, 'Verwaltungswissenschaft, Verwaltungspraxis und die Wissenschaft vom öffentlichen Recht - Eine Bestandsaufnahme' in Mehde Veith, Ramsauer Ulrich, Seckelmann Margrit (eds), Staat, Verwaltung, Information. Festschrift für Hans Peter Bull zum 75. Geburtstag (Duncker\&Humbolt 2011)

Mehde Veith, Wettbewerb zwischen den Staaten (Nomos 2005)

Miąsik Dawid, Andrzej Wróbel, 'Europeizacja prawa administracyjnego pojęcia i konteksty' in Hauser Roman, Wróbel Andrzej, Niewiadomski Zygmunt (eds), Europeizacja prawa administracyjnego. System Prawa Administracyjnego, vol 3 (C.H. Beck 2014)

Neidhardt Stephan, Nationale Rechtsinstitute als Bausteine europäischen Verwaltungsrechts. Rezeption und Wandel zwischen Konvergenz und Wettbewerb der Rechtsordnungen (Mohr Siebeck 2008)

Ochendowski Eugeniusz, 'Pierwszy polski podręcznik prawa administracyjnego. W stulecie wydania podręcznika A. Okolskiego` (1981) 1 Organizacja, Metody, Technika

Oczapowski Józef Bohdan, Policyści zeszłego wieku i nowożytna nauka administracji. Historia nauki administracji $w$ XVIII wieku (Drukiem S. Orgelbranda Synów 1882)

Okolski Antoni, Wyktad prawa administracyjnego oraz prawa administracyjnego obowiązującego w Królestwie Polskim (vol. I - 1880, vol II - 1882, vol III - 1884)

Orlando Emanuele Vittorio (ed), Primo trattato completo di diritto amministrativo (Cammeo\&Vitta 1897)

Panejko Jerzy, Geneza i podstawy samorzadu europejskiego (Imprimerie de Navarre 1926)

Posada Adolfo, Tratado de Derecho administrativo (Suárez 1893)

Scheuner Ulrich, 'Der Einfluss des französischen Verwaltungsrechts auf die deutsche Rechtsentwicklung` (1963) 17/18 Die Öffentliche Verwaltung

Schmidt-Aßmann Eberhard, Dagron Stéphanie, 'Deutsches und französisches Verwaltungsrecht im Vergleich ihrer Ordnungsideen - Zur Geschlossenheit, Offenheit und gegenseitigen Lernfähigkeit von Rechtssystemen` (2007) 67 Zeitschrift für ausländisches öffentliches Recht und Verwaltungsrecht 
Schmidt-De Caluwe Reimund, Der Verwaltungsakt in der Lehre Otto Mayers (Mohr Siebeck 1999)

Schönberger Christoph, 'Verwaltungsrechtsvergleichung: Eigenheiten, Methoden und Geschichte in Bogdandy Armin von, Cassese Sabino, Huber Peter M. (eds), Handbuch Ius Publicum Europaeum: Verwaltungsrecht in Europa: Wissenschaft, vol 4 (C.F. Müller 2011)

Schuppert Gunnar Folke, Politische Kultur (Nomos 2008)

Seckelmann Margrit, 'Ist Rechtstransfer möglich? - Lernen vom fremden Beispiel` (2012) 43 Rechtstheorie

Skarbek hrabia Fryderyk, Gospodarstwo narodowe. Elementarne zasady gospodarstwa narodowego, vol I-II, (Biblioteka Wyższej Szkoły Handlowej 1820)

Supernat Jerzy, 'Koncepcja sieci organów administracji publicznej' in Zimmermann Jan (ed), Koncepcja systemu prawa administracyjnego (Wolters Kluwer 2006)

Wróbel Andrzej, 'Landesspezifische Ausprägungen: Polen' in Bogdandy Armin von, Cassese Sabino, Huber Peter M. (eds), Handbuch Ius Publicum Europaeum: Verwaltungsrecht in Europa: Grundlagen, vol 3 (C.F. Müller 2010)

Zieliński Marek, 'O pojęciu międzynarodowego prawa administracyjnego' (2008) 9 Państwo i Prawo 